\title{
Survival and Success of implants with Laser-Lok Microchannels: A Retrospective Study of Cases with 5-Year Follow-Up
}

\author{
Laser-Lok Mikro Kanallı Implantların Sağkalımı ve Başarısı: 5 Yıllık Takipli \\ Vakaların Geriye Dönük Çalışması
}

\section{Aylin Sipahi CALIS ${ }^{1}$, Banu Ozveri KOYUNCU ${ }^{1}$, Bahar SEZER ${ }^{1}$, Tayfun GUNBAY ${ }^{1}$, Erhan COMLEKOGLU²}

\author{
${ }^{1}$ Ege University School of Dentistry Oral Surgery Dept, Izmır, Turkey \\ ${ }^{2}$ Ege University School of Dentistry Prosthodontics Dept, Izmır, Turkey
}

Atıf/Citation: Calis, A.S., Koyuncu, B.O., Sezer B., Gunbay, T, Comlekoglu, E., (2021). Survival and Success of implants with LaserLok Microchannels: A Retrospective Study of Cases with 5-Year Follow-Up. Ege Üniversitesi Diş Hekimliği Fakültesi Dergisi, 42(2), 139-146.

\begin{abstract}
Purpose: The use of osseointegrated implants as an endoestal anchorage device to provide support for dental prostheses is a reliable and widely accepted treatment modality. The purpose of this study was to evaluate the long-term clinical performance of a dental implant system.

Material and Methods: One hundred fifty-five consecutive patients (71 men, 84 women), aged between 18 and 72 years (mean: 54 years) participated in this study. A total of 500 implants (internal; BioHorizons, Birmingham, AL, USA) were inserted. The cases were examined retrospectively in order to evaluate the clinical efficiency of BioHorizons implants placed and to determine the success rate of implant supported prostheses after a 5-year follow-up period. All implants were assessed clinically and radiographically on a yearly basis.

Results: The 5-year cumulative success rates for maxillary and mandibular implants were $98.7 \%$ and $99.6 \%$, respectively. Among all examined implants, 4 failed to osseointegrate before loading, they were surgically removed and were considered as early failures. Failed implants were not associated with any clinical signs of periimplant infection with suppuration. The most common prosthetic complication was abutment screw loosing.

Conclusion: Within the limitations of the observation period and sample number, the present findings confirmed sufficient success and survival rates for the implants placed in mandible as well as implants placed in the maxilla after a 5-year period.
\end{abstract}

Keywords: Osseointegrated dental implant, bone quality, fixed dental prostheses, overdentures

Öz

Amaç: Protetik tedavilere destek sağlamak amacılla endosteel ankraj olarak osseointegre implantların kullanılması, güvenilir ve yaygın olarak kabul gören bir tedavi yöntemidir. Bu çalışmanın amacı, bir dental implant sisteminin uzun vadeli klinik performansını değerlendirmektir.

Gereç ve yöntem: Bu çalışmaya 18-72 yaşları arasında (ortalama:54 yaş) yüz elli beş ardışık hasta (71 erkek, 84 kadın) katıldı. Toplam 500 implant (BioHorizons, Birmingham, AL, ABD) yerleştirildi. Yerleştirilen BioHorizons implantların klinik etkinliğini değerlendirmek ve 5 yıllık bir takip süresinden sonra implant destekli protezlerin başarı oranını belirlemek için vakalar geriye dönük olarak incelendi. Tüm implantlar yıllık periyotlarda klinik ve radyografik olarak değerlendirildi.

Bulgular: Üst ve alt çene implantlar için 5 yıllık kümülatif başarı oranları sırasıyla\% 98.7 ve\% 99.6 idi. Incelenen implantların 4 'ü yüklemeden önce osseoentegre olamadı, cerrahi olarak çıkarıldı ve erken başarısızlık olarak kabul edildi. Başarısız implantlar, süpürasyonlu periimplant enfeksiyonunun herhangi bir klinik belirtisi ile ilişkili değildi. En sık görülen protez komplikasyonu abutment vidasının gevşemesi idi.

Sonuç: Gözlem süresi ve örnek sayısına göre, mevcut bulgular alt çeneye yerleştirilen implantlar kadar üst çeneye yerleştirilen implantların da 5 yıllık bir sürede yeterli oranda başarılı olduğunu göstermiştir.

Anahtar Kelimeler: Osseoentegre dental implant, kemik kalitesi, sabit protez, hareketli protez 


\section{INTRODUCTION}

The use of osseointegrated dental implants has become a successful procedure for the treatment of complete and partial edentulism. Advances in the understanding of the process of osseointegration and the development of placement techniques that ensure a high success rate have resulted in more applications for implants. ${ }^{1-5}$

Brånemark et al have pioneered the modern-day use of this technology, in which implant materials capable of bearing forces produced during normal function interface both structurally and functionally with bone.

At the beginning of this century, it was reported that there were 25 dental implants manufacturers with marketing about 100 different dental implant systems with variety of diameters, lengths, surfaces, platforms, interfaces, and body shapes. ${ }^{4}$ Significant differentiation and distinctions are based on (i) the implant/abutment interface, (ii) the body shape, and (iii) the implant-tobone surface. This remarkable increased need and use of implant-treatments may result from the combined effect of a number of factors; including aging population, tooth loss related to age, anatomic consequences of edentulism, poor performance of removable prostheses, psychologic aspects of tooth loss, predictable long-term results of implant-supported prostheses and advantages of implantsupported prostheses. ${ }^{6,7}$

Assuming an acceptable level of surgeon's experience and patient's bone quality, reliable implants will result in a more predictable outcome. Since Schnitman and Shulman ${ }^{8}$ proposed success criteria for implants, several criteria have been proposed ${ }^{9,10}$ and the report by Albrektsson et al ${ }^{11}$ is most widely used. ${ }^{12}$

Many studies have considered 1 year after implant placement to be a critical point because the Kaplan-Meier survival curve almost reaches a plateau 1 year after the implant placement. Performance of bone augmentation did not affect the implant success rate or the amount of marginal bone loss. ${ }^{12-14}$

Until recently, various implant systems have been introduced to increase the success rate and research on implant design and surface treatment has been actively performed. ${ }^{15,16}$ Many studies have revealed that the success rate is higher in rough-surfaced implants by various surface treatments than in smooth-surfaced implants by machining. ${ }^{17,18}$ Regarding the morphology of the implants, the initial stability was enhanced by selftapping implants and the success rate was also increased. $12,19,20$

The purpose of this retrospective study was to evaluate the clinical outcome of BioHorizons dental implants placed in the maxilla or in the mandible over a period of 5 years.

\section{MATERIALS AND METHODS}

A retrospective review of implant replacement of lost tooth/teeth over a period of 5 years $(2005-2010)$ at School of Dentistry Ege University, Turkey was carried out. One hundred fifty-five consecutive patients ( 71 men, 84 women), aged between 18 and 72 years participated in this study. The mean age of the patients was 54 years. The inclusion criteria for enrollment in this study were (1) age minimum 18 (2) the presence of any kind of maxillary or mandibular partial or total edentulism (single tooth gap, distal extension, edentulous space in the arch, fully edentulous), (3) sufficient residual vertical bone volume to receive implants of at least $8 \mathrm{~mm}$ in length as assessed by clinical and radiological examination, (4) the absence of periodontal and mucosal diseases, and (5) good general health status.

Exclusion criteria were, (1) a high degree of bruxism, (2) smoking, (3) more than 20 cigarettes/day and excessive consumption of alcohol, (4) localized radiation therapy of the oral cavity, (5) antitumor chemotherapy, (6) liver diseases, (7) blood diseases, (8) kidney diseases, (9) immunosuppressed patients, (10) corticosteroid therapy, (11) pregnancy, (12) inflammatory and autoimmune diseases of the oral cavity, (13) poor oral hygiene.

Implant survival rate was evaluated according to the following criteria: (1) absence of persisting pain or dysesthesia; (2) absence of peri-implant infection with suppuration; (3) absence of mobility; and (4) absence of persisting peri-implant bone resorption greater than

$1.5 \mathrm{~mm}$ during the first year of loading and 0.2 $\mathrm{mm} /$ year during the following years.

\section{Data Collection}

At the initial visit, all patients received clinical and occlusal examination, periapical and panoramic radiographs. The patients presented with one of four different indications (single tooth gap, distal extension inter/intraarch edentulism and fully edentulous).

A total of 500 implants (BioHorizons, Birmingham, AL, USA) were inserted. Implants with lengths of 9, $10.5,12$ or $15 \mathrm{~mm}$ and diameters of $3.8,4.0$ or $5.0 \mathrm{~mm}$ were used. All implants were installed by two experienced surgeons from the Ege University Faculty of Dentistry Department of Oral and Maxillofacial Surgery. The prostheses were fabricated by an experienced prosthodontist (MEÇ) at the Department of Prosthodontics at Ege University.

Of the 500 implants examined here, 243 (48.6\%) were placed in the maxilla, including 116 in anterior region and 127 in posterior region. Two hundred and fifty seven (51.4\%) implants were placed in the mandible, 69 being placed in anterior and 188 placed in posterior regions. The distribution of implants and recipient sites 
are summarized in Table 1. A total of 205 prosthetic restorations were connected to the implants (Table 2).

Table 1. Classifications of implant recipient sites.

\begin{tabular}{lc}
\hline Type of implant recipient site & Number of implants \\
\hline Standard sites (sufficient bone and keratinized mucosa) & $\mathbf{2 0 8}$ \\
\hline $\begin{array}{l}\text { Maxillary sites with deficient posterior alveolar ridge (Sinus lifting or osteotome technique, } \\
\text { implant placement) }\end{array}$ & $\mathbf{8 2}$ \\
\hline $\begin{array}{l}\text { Sites with horizontal bone defect; simultaneous GBR approach (implant placement + membrane } \\
\text { application) }\end{array}$ & $\mathbf{1 7 4}$ \\
\hline $\begin{array}{l}\text { Sites with horizontal bone defect;taged GBR approach (bone grafting + membrane application, no } \\
\text { implant placement) }\end{array}$ & $\mathbf{3 6}$ \\
\hline Total & $\mathbf{5 0 0}$ \\
\hline
\end{tabular}

Table 2. Prosthetic rehabilitation procedures performed

\begin{tabular}{lccc}
\hline Prosthetic restoration & Maxilla & Mandible & Total \\
\hline Full-arch bridge (8 implants) & 96 & 80 & 176 \\
\hline Overdenture (Dolder bar- 4 implants) & 8 & 4 & 12 \\
\hline Overdenture (Ball anchors 2 implants) & 20 & 30 & 50 \\
\hline Single tooth replacement & 44 & 36 & 80 \\
\hline Short-span fixed bridges & 80 & 102 & 182 \\
\hline Total & 248 & 252 & 500 \\
\hline
\end{tabular}

\section{Surgical and Prosthetic Techniques}

Diagnostic impressions were made with an irreversible hydrocolloid (CA37; Cavex, The Netherlands). Impressions were poured with a Type IV dental stone (GC Fujirock EP; GC Europe, Belgium). Surgical guides were prepared by an imprint of the diagnostic wax-up, which were converted to working plaster models. Periapical and panoramic radiographs were obtained before surgery for all patients. Patients received informed consent forms.

All patients underwent the same surgical protocol. Antimicrobial prophylaxis was obtained with mouthrinses of $0.12 \%$ chlorhexidine gluconate solution (three times a day for 7 days starting 3 days before surgery) and antibiotics ( $2 \mathrm{~g}$ /day of clavulanic acid and amoxicillin for 3 days starting 1 hour before surgery). Local anesthesia was induced by infiltration with $2 \mathrm{ml}$ of Jetocaine ${ }^{\circledR}$ (Adeka, Istanbul, Turkey) (Lidocaine $\mathrm{HCl}$ ).

Implants were placed according to the manufacturer protocol. Bone quality classification was performed at the time of surgery by the oral surgeon on the basis of hand-feeling persistence of the drilling resistance according to the classification of Trisi and Rao. 21 Implants placed in sites with good bone quality were examined after a healing period of three-four months in the maxilla or two-three months in the mandible. Implants placed in sites with poor bone quality (soft), or grafting area were examined after a five or six months healing period. The patients received clinical and radiographic evaluation at the above designated appropriate healing time.

The implant immobility was tested by resonance frequency analysis (RFA) (Osstell Mentor, Sweden) after 3-6 months and implants having an implant stability quotient (ISQ) higher than 65 were restored. Manufacturer-recommended screw torque values (30 $\mathrm{Ncm}$ ) were used. Types of prosthetic restorations included maxillary full-arch fixed dental prostheses (FDP), mandibular overdentures supported with ball anchors and short-span FDP and crowns. The occlusion in definitive FDP were established as with simultaneous contacts in maximal intercuspation, canine protected articulation, or group function during working side movements, and absence of interferences during nonworking side movements. All metal-ceramic FDP fabricated from a nonprecious metal alloy (Wiron 99, Bego, Germany) with a feldspathic veneering ceramic (Vita Omega; VITA Zahnfabrik, Germany) were cemented with a zinc polycarboxylate cement (Poly-F, Dentsply, UK). Overdentures were retained over ball anchors by a chairside implant-abutment connection procedure after definitive denture fabrication. Bilateral balanced occlusion was established for these patients.

The maxillary fullarch bridges were retained by implants placed in positions 11-13-15-17-21-23-25-27 
and the mandibular in positions 31-33-35-37-41-43-4547. Patients who were treated with overdenture supported with dolder bars received the implants positioned in mandible 34-32-42-44, in maxilla 14-12-22-24. Overdentures supported with ball anchors received the implants installed in position 33-43. None of the overdentures in maxilla was supported with ball anchors.

\section{Assessments}

At review appointments, implants were tested manually for mobility and were examined for signs of infection. Crestal bone loss was assessed by manual probing and also by periapical radiographs, obtained by a nonstandardized, long-cone paralleling technique with use of an XCP positioner (Dentsply Rinn, Elgin, Ill.). Crestal bone loss (from baseline to the end of the observation period) was categorized as follows: 0 to 1 $\mathrm{mm}>1$ to $2 \mathrm{~mm},>2$ to $3 \mathrm{~mm},>3$ to $4 \mathrm{~mm},>4$ to $5 \mathrm{~mm}$ and $>5 \mathrm{~mm}$. Implants were considered successful only if crestal bone loss was no more than $4 \mathrm{~mm}$. Any adverse events reported by the patients were recorded. Other assessments included oral hygiene and periodontal status, although the findings were documented only if they were considered outside the normal range.

\section{Implant Outcome (Success, Survival and Failure Criteria)}

Implants were classified in 1 of the following 3 categories according to outcome.

Surviving implant: Implant that remained in situ and in function, whether or not there were any complications, such as exudate, facial space abscess, local implant fistula, pain or swelling at the implant site, purulence, periimplant radiolucency and/or crestal bone loss greater than $4 \mathrm{~mm}$.

Successful implant: Surviving implants that also fulfilled the following criteria: ${ }^{2,11,16}$

- absence of mobility, assessed manually and by a manual torque test

- absence of peri-implant radiolucency

- absence of continuous pain or suppuration around the implant

- absence of deep ( $>5 \mathrm{~mm}$ ) pockets adjacent to the implant

- bone loss $<4 \mathrm{~mm}$

Failed implant: Implant that had been removed for any reason, pain, mobility or advanced bone loss. Early failures were those occurring up to 1 year after the surgery but before prosthetic restoration. Late failures were those occurring more than 1 year after implant placement or after restoration.

All implants were subsequently assessed clinically and radiographically at seven follow-up examinations which occurred 1, 6, 12, 24, 36, 48 and 60 months after prosthesis placement.

Radiographic evaluation was performed by either periapical radiographs obtained by long-cone paralleling technique or panoramic radiographs. In patients who were treated with overdentures or full-arch bridges supported with multiple implants a panoramic radiograph was used. In partially edentulous patients periapical radiographs were used. Radiographs were analyzed for presence peri-implant radiolucencies.

\section{Statistical Analysis}

All clinical data were entered into an electronic database. The statistical software SPSS version 22.0 was used for analysis and Microsoft word and excel were used to generate tables. Descriptive statistics was computed for all the variables. The Chi-square test was used to evaluate the uniformity in the distrubition of patients and implants. The success of the implant was analyzed by Kaplan-Meier survival analysis.

Life tables included the following parameters: observation time, number of implants at the start of each interval, number of failed implants during each interval, number of implants not subjected to follow-up examination due to patient drop-out, annual survival and success rates and cumulative survival and success rates. Cumulative success rates, which took into account failure conditions in addition to failed implants, were calculated for each jaw.

\section{RESULTS}

155 (71 men, 84 women) patients who had 500 implants installed in their maxilla and/or mandibles were included in the study. The mean age of the patients at the time of implant placement was 54 years (range 18 to 72 years). The patients presented with one of five different indications (80 implants for single restorations, 92 for distal extensions, 90 edentulous spaces in the arch, 238 fully edentulous). $64 \%$ of single and multiple-unit implant retained FDP were cemented and $36 \%$ were screw retained. Of the 500 examined implants, 4 (two in anterior maxilla, one in posterior maxilla, one in posterior mandible) did not integrate before loading and revealed chronic periimplant infection. These were considered as early failures and this resulted in $0.8 \%$ early failure rate (Tables 3 and 4). These implants were replaced with new implants after the implant removal.

During the healing period the remaining implants showed no clinical signs of inflammation and/or periimplantitis radiolucencies. Osseointegrated 500 implants did not show signs of peri-implant infection and/or peri-implant radiolucencies. 
Table 3. Distribution and timing of implant failures.

\begin{tabular}{|l|c|l|l|l|l|}
\hline \multirow{2}{*}{ Implant location } & \multirow{2}{*}{$\begin{array}{l}\text { No of implants } \\
\text { inserted }\end{array}$} & \multirow{2}{*}{$\begin{array}{l}\text { Early failures during } \\
\text { healing }\end{array}$} & \multicolumn{3}{|c|}{ Implant removal } \\
\cline { 4 - 6 } & 116 & 2 & 2 & - & - \\
\hline Maxilla Anterior & 127 & 1 & 1 & - & - \\
\hline Maxilla Posterior & 69 & - & - & - & - \\
\hline Mandible Anterior & 188 & 1 & 1 & 1 & 2 \\
\hline Mandible Posterior & 500 & 4 & 4 & 1 & 2 \\
\hline Total & & & & years & - \\
\hline
\end{tabular}

Table 4. Characteristics of failed implants.

\begin{tabular}{|l|l|l|l|l|}
\hline Implant location & Failure time & Implant length & Implant diameter & Reason for failure \\
\hline 24 & Early & 12 & 3.8 & Mobility \\
\hline 14 & Early & 12 & 3.8 & Mobility \\
\hline 16 & Early & 12 & 5.2 & Mobility \\
\hline 45 & Early & 12 & 4.1 & Mobility \\
\hline
\end{tabular}

Three prosthetic complications were present after 5 years of functioning period (Table 5).

The interval examination and entire 5-year period success rates are summarized in Table 6 . The cumulative one-year survival rates of implants were $98.28 \%$ for the maxilla and $99.22 \%$ for the mandible. Hence, the life table analysis indicated that the 5-year functioning cumulative success rates were $98,8 \%$ for maxillary implants and 98,4\% for mandibular implants.

Table 5. Prosthetic complications encountered in the study.

\begin{tabular}{|c|c|c|c|c|}
\hline & Screw loosening & Abutment loosening & Veneer fracture & Abutment fracture \\
\hline Mandible & 1 & - & 1 & 1 \\
\hline Maxilla & - & - & - & - \\
\hline
\end{tabular}

Table 6. Success rates and cumulative success rate of implants.

\begin{tabular}{lccccc}
\hline Interval (years) & $\begin{array}{c}\text { Implants at start } \\
\text { of interval }\end{array}$ & $\begin{array}{c}\text { Drop outs during } \\
\text { interval }\end{array}$ & $\begin{array}{c}\text { Failures during } \\
\text { interval }\end{array}$ & $\begin{array}{c}\text { Success rate } \\
\text { within period } \\
\mathbf{( \% )}\end{array}$ & $\begin{array}{c}\text { Cumulative } \\
\text { success rate } \\
\text { (\%) }\end{array}$ \\
\hline $\mathbf{0 - 1}$ & 500 & 0 & 4 & 99.17 & 99.17 \\
\hline $\mathbf{1 - 2}$ & 463 & 0 & 1 & 99.77 & 98.94 \\
\hline $\mathbf{2 - 3}$ & 387 & 0 & 1 & 99.71 & 98.65 \\
\hline $\mathbf{3 - 4}$ & 298 & 0 & 1 & 99.50 & 98.15 \\
\hline $\mathbf{4 - 5}$ & 96 & 0 & - & 1.00 & 98.15 \\
\hline
\end{tabular}

\section{DISCUSSION}

Following the introduction of concept and practice of the osseintegration into restorative dentistry in the early $1960 \mathrm{~s},{ }^{1}$ completely edentulous mandibular arches in elderly patients received primary emphasis regarding the restoration of oral function. Following excellent longterm results in the treatment of completely edentulous arches, implant-supported fixed partial dentures and overdentures became common treatment modalities. ${ }^{7}$
In the present study, as in previous studies on the long-term results of implant therapy, the implant losses were concentrated in a large number of individuals.

Initial losses during the healing phase were related with absence of osseointegration. Of the 500 implants that were inserted in the current study, four failed because of iatrogenic factors where the removal of these implants was necessary. Two failures were attributed to occlusal loading of antagonist teeth/mandibular prosthesis. Other 
implants placed at the same time and in the same patients were successfully osseointegrated. The other failure was caused by infection but the other one failed to osseointegrate because of unknown reasons. Failure of endosseous implants is either early or late, depending on whether it occurs before or after occlusal loading with a prosthetic superstructure. ${ }^{22}$ Most failures occur early, so the recognition of potential risk factors of early failure is important. $^{23}$

Early failure of dental implants is thought to be caused by failure of bony healing around the implant and subsequent failure of osseointegration; this could be attributed to local or systemic factors. ${ }^{1,8}$ Despite using well-documented dental implant systems, the possession of adequate clinical experience, the use of measures to avoid cross infection, and the adequacy of soft and hard tissues, implants could fail early after insertion. The reported early failure rate is from $0.8 \%$ to $4 \%$.

An early failure of an implant results from "an inability to establish an intimate bone-to-implant contact', ${ }^{24,25}$ This means that bone healing after implant insertion is impaired or even jeopardized. Both systemic and local factors can interfere with these primarily cellular events. The mechanisms that normally lead to wound healing by means of bone apposition do not take place, and rather a fibrous scar tissue is formed in between the implant surface and surrounding bone. ${ }^{24}$ This can lead to epithelial downgrowth, a so called saucerization or marsupialization of the implant, which results in mobility or even implant loss.

In a study, Gokcen-Rohlig et al evaluated the clinical efficiency of non-submerged Straumann implants and determined the success rate of implant retained/supported prosthesis after a 5-year period and found cumulative success rates for maxillary and mandibular implants as $91.00 \%$ and $97.81 \%$, respectively. ${ }^{26}$ In another study, Ferrigno et al evaluated the long-term prognosis of 1286 non-submerged Straumann implants in fully edentulous arches and reported a cumulative survival rate of $95.9 \%$ and a cumulative success rate of $92.7 \%$ in ten years. ${ }^{27}$ Jemt and Johansson reported 15-year patient-based data in relation to time of follow-up after treatment with fixed prostheses supported by implants in the edentulous upper jaws and found the 15-year implant and fixed prosthesis cumulative survival rates as 90.9 and $90.6 \%$, respectively. ${ }^{28}$ Capelli et al assessed the treatment outcome of immediately loaded full-arch screw-retained prostheses with distal extensions supported by both upright and tilted implants for the rehabilitation of edentulous jaws and reported the cumulative implant survival rate for the maxilla was $97.59 \%$ for up-to-40 months of follow-up and no implant failure was recorded for the mandible. ${ }^{29}$ Chiapasco prospectively evaluated survival and success rates of implants placed in the interforaminal area of edentulous mandibles and immediately loaded with an implant-supported overdenture and found the absolute success and survival rates as $91.6 \%$ and $97.6 \%$, respectively, whereas the cumulative survival and success rates of implants obtained with a life table analysis were $96.1 \%$ and $88.2 \%$, respectively.30 In a clinical study, Kim et al found that the short-term survival rate of Astra Tech implants was $100 \%$ regardless of bone quality, bone quantity, or use of bone augmentation procedures. ${ }^{12}$

Degidi et al. evaluated a total of 550 implants (Maestro; BioHorizons, Birmingham, AL, USA) and found that in the immediately loaded implants group, three implants failed, all in posterior mandibular sites, with an overall $98.8 \% 5$-year survival rate. In the control group, no implant failed, with a 100\% 5-year survival rate. ${ }^{31}$ In a prospective study ${ }^{32}$ using a bone quality-based implant system (Maestro; BioHorizons, Birmingham, AL, USA), it was reported that no implant failure occurred, and crestal bone loss values were similar to or less than values reported with the conditional two-stage approach. In another prospective study Misch et al assessed a bone quality-based (Biohorizons) implant system, with four implant designs and found that the surgical survival of 975 implants was $99.4 \%$, with the survival $100 \%$ for D4 bone. ${ }^{33}$

A significant relationship between smoking habits and implant loss was not found in this study. Nevertheless, due to the small number of smokers, this result could be biased. It should be noted that one smoker lost one implant due to chronic trauma of the prostheses.

A number of studies have shown that success and survival rates for the upper jaw are significantly lower than those for the lower jaw. ${ }^{1,34,35,36}$ In our study, initial losses during the healing phase was observed three in the maxilla and one in the mandible.

On the other hand, a recent meta-analysis reported that, in partially edentulous patients, titanium implants with a rough surface had significantly higher success rates in the maxilla than in the mandible. Our 5-year functioning cumulative success rate for maxillary implants $(98.8 \%)$ was consistent with the literature, our 5 -year functioning cumulative success rate for mandibular implants $(98,4 \%)$ was lower than that reported previously.

Abutment screw loosening as a prosthetic complication in the present study could be attributed to metal fatigue behavior after cyclic occlusal loading after 5 years. This problem was solved by drilling a hole from the occlusal surface of FDP and applying torque with a torque device and filling the cavity with a composite resin after obturating the screw hole with a teflon tape.

Although implant survival and implant success rates often tend to slowly decline after 5 years in function, this trend was not observed in the present study. 
When considering implant success, it is advisable to evaluate not only the implant survival rate but also the implant success rate. It is then necessary to study biological and technical complications.

\section{CONCLUSION}

Osseointegrated implants have become an extremely valuable treatment option in prosthetic reconstruction. This clinical study exhibited excellent long-term outcomes with high survival rates of BioHorizons implants placed in the mandible as well as implants placed in the maxilla after a 5-year period.

\section{Compliance with ethical standards}

\section{Conflict of interest}

The authors declare that they have no conflict of interest.

\section{REFERENCES}

1. Adell R, Eriksson B, Lekholm U, Brånemark PI, Jemt T. Longterm follow-up of osseointegrated implants in the treatment of totally edentulous jaws. Int J Oral Maxillofac Implants 1990; 5:347-359.

2. Cochran DL. The scientific basis for and clinical experiences with Straumann implants including the ITI Dental Implant System: a consensus report. Clin Oral Implants Res 2000;11(Suppl):33-58.

3. Bahat $\mathrm{O}$. Brånemark system implants in the posterior maxilla: clinical study of 660 implants followed for 5 to 12 years. Int. J Oral Maxillofac Implants 2000; 15:646-653.

4. Levine RA, Clem D, Beagle J, et al. Multicenter retrospective analysis of the solid-screw ITI implant for posterior singletooth replacements. Int. J Oral Maxillofac Implants 2002; 17:550-556.

5. Fugazzotto PA, Vlassis J, Butler B. ITI implant use in private practice: clinical results with 5,526 implants followed up to 72 months in function. Int. J Oral Maxillofac Implants 2004; 19: 408-412.

6. Misch, C.E. In Contemporary Implant Dentistry; Misch, C.E., Ed.; Mosby, Inc.: St. Louis, MO, USA Chapter 1,1999; p. 3.

7.Oshida Y, Tuna EB, Aktören O, Gençay K. Dental implant Systems.Int. J. Mol. Sci 2010; 11: 15801678.

8. Schnitman PA, Shulman LB. Recommendations of the consensus development conference on dental implants. J Am Dent Assoc 1979;98: 373-377.

9. Smith DE, Zarb GA. Criteria for success of osseointegrated endosseous implants. J Prosthet Dent 1989; 62:567-572.

\section{Funding}

This study is not supported by an institution.

\section{Ethical approval}

All procedures performed in studies involving human participants were in accordance with the ethical standards of the institutional and/or national research committee and with the 1964 Helsinki declaration and its later amendments or comparable ethical standards. The study was approved by Ege University Faculty of Medicine's Clinical Research Ethics Committee.

\section{Informed consent}

Informed consent was obtained from all individual participants included in the study.

10. Buser D, Weber HP, Lang NP. Tissue integration of non-submerged implants. 1-year results of a prospective study with 100 ITI hollow-cylinder and hollow-screw implants. Clin Oral Implants Res 1990; 1:33-40.

11. Albrektsson T, Zarb G, Worthington P, Eriksson AR. The long-term efficacy of currently used dental implants: a review and proposed criteria of success. Int J Oral Maxillofac Implants 1986; 1:11-25.

12. Kim JS, Sohn JY, Park JC, Jung UW, Kim CS, Lee JH, Shim JS, Lee KW, Choi SH. Cumulative survival rate of Astra Tech implants: a retrospective analysis. J Periodontal Implant Sci Apr 2011; 41(2): 86-91.

13. Schliephake H, Neukam FW, Wichmann M. Survival analysis of endosseous implants in bone grafts used for the treatment of severe alveolar ridge atrophy. Oral Maxillofac Surg.1997;Nov;55(11):1227-1233; discussion 1233-4.

14. Finne K, Rompen E, Toljanic J. Clinical evaluation of a prospective multicenter study on 1-piece implants. Part 1: marginal bone level evaluation after 1 year of follow-up. Int $\mathrm{J}$ Oral Maxillofac Implants.2007; Mar-Apr;22(2):226-234.

15. van Steenberghe D, De Mars G, Quirynen M, Jacobs R, Naert I. A prospective split-mouth comparative study of two screw-shaped self-tapping pure titanium implant systems.Clin Oral Implants Res.2000; Jun;11(3):202-209.

16. Cochran DL.A comparison of endosseous dental implant surfaces. J Periodontol.1999; Dec; 70(12):1523-1539.

17. Li DH, Liu BL, Zou JC, Xu KW. Improvement of osseointegration of titanium dental implants by a 
modified sandblasting surface treatment: an in vivo interfacial biomechanics study.Implant Dent.1999;8(3):289-294.

18. Botticelli D, Berglundh T, Persson LG, Lindhe J. Bone regeneration at implants with turned or rough surfaces in self-contained defects. An experimental study in the dog.J Clin Periodontol. 2005; May; $32(5): 448-455$

19. Rosenlicht JL. Swiss Plus Implant System, Part 1: Surgical aspects and intersystem comparisons. Implant Dent.2002;11(2):144-153.

20. Davarpanah M, Martinez H, Etienne D, Zabalegui I, Mattout P, Chiche F, Michel JF. A prospective multicenter evaluation of 1,583 $3 \mathrm{i}$ implants: 1 - to 5 year data. Int J Oral Maxillofac Implants 2002; NovDec;17(6):820-828.

21. Trisi P, Rao W. Bone classification: clinicalhistomorphometric comparison. Clin Oral Implants Res. 1999; Feb;10(1):1-7.

22. Alsaadi G, Quirynen M, Komárek A, Van Steenberghe D. Impact of local and systemic factors on the incidence of oral implant failures, up to abutment connection. J Clin Periodontol 2007; $34: 610-617$.

23. Koldsland AA, Scheie AM. Prevalence of implant loss and the influence of associated factors, J Periodontol 2009;80:1069-1075.

24. Esposito M, Hirsch JM, Lekholm U, Thomsen P. Biological factors contributing to failures of osseointegrated oral implants. (I). Success criteria and epidemiology.Eur J Oral Sci.1998; Feb;106(1):527-551.

25. Quirynen M, De Soete M, van Steenberghe D. Infectious risks for oral implants: a review of the literature.Clin Oral Implants Res.2002; Feb;13(1):119.

26.Gokcen-Rohlig B, Yaltirik M, Ozer S, Tuncer E D, Evlioglu G. Survival and Success of ITI Implants and Prostheses: Retrospective Study of Cases with 5Year Follow-Up. Eur J Dent 2009; January; 3(1): 42 49.

27. Ferrigno N, Laureti M, Fanali S, Grippaudo G.A long-term follow-up study of non-submerged ITI implants in the treatment of totally edentulous jaws. Part I: Ten-year life table analysis of a prospective multicenter study with 1286 implants.Clin Oral Implants Res. 2002; Jun;13(3):260-273.

28. Jemt T, Johansson J. Implant treatment in the edentulous maxillae: a 15-year follow-up study on 76 consecutive patients provided with fixed prostheses.Clin Implant Dent Relat Res.2006;8(2):61-69.

29. Capelli M, Zuffetti F, Del Fabbro M, Testori T. Immediate rehabilitation of the completely edentulous jaw with fixed prostheses supported by either upright or tilted implants: a multicenter clinical study.Int $\mathrm{J}$ Oral Maxillofac Implants. 2007;Jul-Aug;22(4):639-644.

30. Chiapasco M.Early and immediate restoration and loading of implants in completely edentulous patients. Int J Oral Maxillofac Implants. 2004;19 Suppl:76-91.

31. Degidi M, Iezzi G, Perrotti V, Piattelli A. Comparative Analysis of Immediate Functional Loading and Immediate Nonfunctional Loading to Traditional Healing Periods: A 5-Year Follow-Up of 550 Dental Implants. Clinical Implant Dentistry and Related Research 2009; Dec;11(4):257 - 266.

32. Misch E, Carl \& Degidi, Marco \& E. Misch, Carl \& Degidi, Marco. Five-Year Prospective Study of Immediate/Early Loading of Fixed Prostheses in Completely Edentulous Jaws with a Bone QualityBased Implant System. Clinical Implant Dentistry and Related Research 2003; 5:17-19.

33. Misch CE, Dietsh-Misch F, Hoar J, Beck G, Hazen $\mathrm{R}$, Misch CM. A bone quality-based implant system: first year of prosthetic loading.J Oral Implantol.1999; 25(3):185-197.

34. Bass SL, Triplett RG. The effects of preoperative resorption and jaw anatomy on implant success. A report of 303 cases.Clin Oral Implants Res.1991; Oct-Dec;2(4):193-198.

35. Jaffin RA, Berman CL.The excessive loss of Branemark fixtures in type IV bone: a 5-year analysis. J Periodontol. 1991; Jan; 62(1):2-4.

36. Buser D, Mericske-Stern R, Bernard JP, Behneke A, Behneke N, Hirt HP, Belser UC, Lang NP.Long-term evaluation of non-submerged ITI implants. Part 1: 8year life table analysis of a prospective multi-center study with 2359 implants. Clin Oral Implants Res. Jun1997;8(3):161-172. 